\title{
Device Contaminated during Manufacturing or Shipping
}

National Cancer Institute

\section{Source}

National Cancer Institute. Device Contaminated during Manufacturing or Shipping. NCI

Thesaurus. Code C63019.

Problem associated with the presence of any unexpected foreign substance found on the surface or in the package materials, which may affect optimal performance for its intended use. 